\title{
JUST OUT OF REACH: CONGRESS, COURTS, AND INDUSTRY STRUGGLE TO DEFINE THE SCOPE OF U.S. PATENT LaW Overseas
}

\author{
Katharine H. Cummings ${ }^{\dagger}$
}

\section{INTRODUCTION}

Since the first Congress enacted the original Patent Act in 1790, Congress has generally continued to limit the reach of United States patent law to activity within the nation's borders. ${ }^{1}$ Congress wrote this limitation into the current Patent Act, restricting its reach to activity within and imports into the United States. ${ }^{2}$ The presumption against extraterritoriality-a tool of statutory interpretation-reinforces the statute's express geographic limitations. This is the presumption that "legislation of Congress, unless a contrary intent appears, is meant to apply only within the territorial jurisdiction of the United States."3 The presumption against extraterritoriality applies "unless there is the affirmative intention of the Congress clearly expressed' to give a statute extraterritorial effect."

\footnotetext{
DOI: https://doi.org/10.15779/Z38KK94C47

(C) 2018 Katharine H. Cummings.

† J.D. Candidate, 2019, University of California, Berkeley, School of Law.

1. See Patent Act of 1790 , ch. 7, \ 4, 1 Stat. 109, 111 (" $[$ f f any person or persons shall devise, make, construct, use, employ, or vend within these United states, any art, manufacture, engine, machine or device... the sole and exclusive right of which shall be so as aforesaid granted by patent ....').

2. See 35 U.S.C. \271(a) (2012) ("Except as otherwise provided in this title, whoever without authority makes, uses, offers to sell, or sells any patented invention, within the United States or imports into the United States any patented invention during the term of the patent therefor, infringes the patent.").

3. Foley Bros. v. Filardo, 336 U.S. 281, 285 (1949) (applying the presumption against extraterritoriality to hold that a federal employment statute did not apply to work performed in foreign countries); see also Microsoft Corp. v. AT\&T Corp., 550 U.S. 437, 454-55 (2007) ("The presumption that United States law governs domestically but does not rule the world applies with particular force in patent law.").

4. Morrison v. Nat'l Australia Bank Ltd., 561 U.S. 247, 255 (2010) (quoting EEOC v. Arabian Am. Oil Co., 499, U.S. 244, 248 (1991)).
} 
In 35 U.S.C. \271(f), ${ }^{5}$ enacted in 1984, ${ }^{6}$ Congress expressly rebutted patent law's strong presumption against extraterritoriality ${ }^{7}$ by allowing infringement liability based on certain extraterritorial actions. ${ }^{8}$ The exact limits of $\int 271(\mathrm{f})$, however, were not clear.

The Supreme Court addressed \271(f) in Life Technologies v. Promega. ${ }^{9}$ In Life Technologies, Promega alleged infringement against Life Technologies for exporting one component of a patented multicomponent product from the United States to be assembled abroad. ${ }^{10}$ The Federal Circuit interpreted the statute broadly and greatly expanded the reach of U.S. patent law overseas. ${ }^{11}$ The Supreme Court reversed. It determined that a party exporting a single component of a multicomponent patented invention for assembly abroad does not infringe under $\int 271(\mathrm{f})(1) .{ }^{12}$ The Court elected not to address issues surrounding induced infringement, but rather allowed those issues to percolate in the lower courts. ${ }^{13}$

The Supreme Court correctly restrained the extraterritorial application of \271(f) in Life Technologies. Although \271(f) explicitly provides for some extraterritorial application, the precise bounds of the statute's extraterritorial

5. 35 U.S.C. \271(f) (2012).

6. Patent Law Amendments Act of 1984, Pub. L. No. 98-622, 98 Stat. 3383 (1984) (codified as amended in scattered sections of Title 35 in the United States Code).

7. See Microsoft Corp., 550 U.S. at 442.

8. 35 U.S.C. $\int 271(\mathrm{f})(2012)$ states:

(1)Whoever without authority supplies or causes to be supplied in or from the United States all or a substantial portion of the components of a patented invention, where such components are uncombined in whole or in part, in such manner as to actively induce the combination of such components outside of the United States in a manner that would infringe the patent if such combination occurred within the United States, shall be liable as an infringer.

(2)Whoever without authority supplies or causes to be supplied in or from the United States any component of a patented invention that is especially made or especially adapted for use in the invention and not a staple article or commodity of commerce suitable for substantial noninfringing use, where such component is uncombined in whole or in part, knowing that such component is so made or adapted and intending that such component will be combined outside of the United States in a manner that would infringe the patent if such combination occurred within the United States, shall be liable as an infringer.

9. 137 S. Ct. 734 (2017).

10. See id. at 738 .

11. Promega Corp. v. Life Techs. Corp., 773 F.3d 1338, 1356 (Fed. Cir. 2014), rev'd and remanded, 137 S. Ct. 734 (2017).

12. See Life Techs., 137 S. Ct. at 737.

13. See Life Techs. Corp. v. Promega Corp., 136 S. Ct. 2505 (2016) (writ of certiorari granted limited to Question 2). 
reach are unclear. The section should not be interpreted to allow for unjustifiably broad extraterritorial application of United States patent law. The long history of restrictions on extraterritorial applications of United States patent law counsels toward a narrow reading of $\int 271(\mathrm{f})$. While some practitioners have lamented the Court's decision to strike down the Federal Circuit's broad interpretation of $\int 271(\mathrm{f})$ without providing its own thorough interpretation of the statute or analysis of its elements, the Supreme Court's minimalist decision befits its status as a court of last resort. By declining to articulate the precise bounds of $\int 271(\mathrm{f})$, the Court correctly declined to issue an advisory opinion. ${ }^{14}$ Rather, the Court opted to allow lower courts to address the limits of $\int 271(\mathrm{f})$.

Part II of this Note discusses the history of the presumption against extraterritoriality and the presumption's application to U.S. patent law. Part II also explores the origin of $\int 271(\mathrm{f})$ and Congress's intent to rebut the presumption against extraterritorial application. Part III sets forth the Life Technologies v. Promega case, the Federal Circuit's expansive opinion, and the Supreme Court's concise reversal. Part IV analyzes the Supreme Court's opinion in Life Technologies in light of its objectives as the court of last resort. Part V concludes that, while the Court's opinion may not have been as comprehensive as practitioners and others would have liked, it did succeed in restraining the external expansion of U.S. patent law while enabling future clarification and interpretation of $\$ 271(\mathrm{f})$.

\section{THE PRESUMPTION AGAINST EXTRATERRITORIALITY SHAPES U.S. PATENT LAW}

The presumption against extraterritoriality has origins in patent law dating back over 150 years. ${ }^{15}$ In light of this long history, the Supreme Court has been hesitant to rebut the presumption, even when Congress has expressly communicated a desire to expand the reach of U.S. patent law overseas, as it did in $\int 271(\mathrm{f}) .{ }^{16}$ The Court's resistance is partly due to $\int 271(\mathrm{f})$ 's ambiguous language, which does not clearly indicate when the exception should apply. Although the Supreme Court has not provided a bright-line interpretation of \271(f)'s bounds, the context and "remainder of the statutory scheme" give

14. See Life Techs., 137 S. Ct. at 743 (Alito, J. concurring) ("[T]oday's opinion establishes that more than one component is necessary, but does not address how much more.").

15. See Brown v. Duchesne, 60 U.S. 183, 195 (1856) (stating that Congress's power to enact patent laws is "domestic in its character, and necessarily confined within the limits of the United States”).

16. See Microsoft Corp. v. AT\&T Corp., 550 U.S. 437, 442 (2007) ("Recognizing that $\int 271(f)$ is an exception to the general rule that our patent law does not apply extraterritorially, we resist giving the language in which Congress cast $\int 271(\mathrm{f})$ an expansive interpretation."). 
courts and practitioners insight into interpreting the statute. ${ }^{17}$

\section{A. Early Origins of the Presumption Against \\ EXTRATERritoriality IN PATENT LAW: BROWN V. DUCHESNE}

The Supreme Court has been steadfast in maintaining the territoriality of patent law since as early as 1856. In 1856, the Court addressed the geographic reach of United States patent law in Brown v. Duchesne. ${ }^{18}$ In that case, Duchesne sailed a ship from France to the port of Boston to trade. ${ }^{19}$ The ship was made in France and had an "improvement" built into it as part of its original equipment. ${ }^{20}$ Brown had a U.S. patent on this improvement and sued Duchesne for infringement. ${ }^{21}$ The Court was asked

whether any improvement in the construction or equipment of a foreign vessel, for which a patent has been obtained in the United States, can be used by such vessel within the jurisdiction of the United States, while she is temporarily there for the purposes of commerce, without the consent of the patentee..$^{22}$

The Court turned to the Constitution to find its answer: "Congress shall have the power to ... promote the Progress of Science and the useful Arts, by securing for limited Times to Authors and Inventors the exclusive Right to their respective Writings and Discoveries." ${ }^{23}$ Chief Justice Taney, writing for the Court, found that this language conferred "no power on Congress to regulate commerce, or the vehicles of commerce, which belong to a foreign nation, and occasionally visit [U.S.] ports in their commercial pursuits." 24 Further, the Court cautioned that Congress must stay within the limits of its legislative authority and that it should not be "presumed that [Congress] intended to go beyond" those limits when "legislating to protect authors and inventors." 25 There is nothing "in the patent laws that should lead to a different conclusion." 26

The Court admitted that there was "technical damage, in the eye of the law" because the use of the improvement on Duchesne's ship trespassed on Brown's U.S. patent rights. ${ }^{27}$ However, the Court qualified this statement by

17. United Sav. Ass'n v. Timbers of Inwood Forest Assocs., 484 U.S. 365, 371 (1988).

18. Brown, 60 U.S. at 194.

19. Brown v. Duchesne, 4 F. Cas. 369, 369 (C.C.D. Mass. 1855), aff'd, 60 U.S. 183 (1856).

20. Id.

21. See id.

22. Brown, 60 U.S. at 194.

23. U.S. CONST. art. I, $\int 8, \mathrm{cl} .8$.

24. Brown, 60 U.S. at 195.

25. Id. (emphasis added).

26. $I d$.

27. Id. 
questioning the idea that U.S. patent laws could have authority over "improvements on foreign ships, lawfully made in their own country, which have been patented" in the United States. ${ }^{28}$ Accordingly, the Court determined that finding infringement would require reaching beyond the domestic limits of patent laws. Holding Duchesne liable would give Brown and other patent owners the power to influence the actions of foreign nations that would "seriously embarrass the commerce of the [United States] with foreign nations." ${ }^{29}$ Further, finding liability here would "embarrass the [United States"] treaty-making power in its negotiations with foreign nations, and also [would] interfere with the legislation of Congress when exercising its constitutional power to regulate commerce." 30 The Court suggested that Congress would be the appropriate body to negotiate treaties regulating the admittance of foreign ships to U.S. ports, not the Court in granting relief to a plaintiff. ${ }^{31}$

The Court was aware of the global repercussions of holding that the French ship infringed a U.S. patent. Looking to avoid such a political statement, the Court presumed that Congress did not intend to extend patent laws in such a way as to affect extraterritorial actions. Thus, the Court determined that since the power and reach of the patent laws are "necessarily [domestic] and confined within the limits of the United States," the foreign defendant was not liable for infringement. ${ }^{32}$ Inspired by foreign policy concerns, the Court concluded that "the rights of property and exclusive use granted to a patentee [do] not extend to a foreign vessel lawfully entering" a U.S. port. ${ }^{33}$

\section{B. The Presumption Persists: Deepsouth PACKing V. Laitram}

Over 100 years after Brown v. Duchesne, the Supreme Court again addressed the notion of extraterritoriality in patent law. In Deepsouth Packing v. Laitram, Laitram sued Deepsouth for infringement of its patents on shrimp deveining machinery. ${ }^{34}$ The patents at issue were combination patents. ${ }^{35}$ Combination patents comprise components, none of which are novel or patentable alone, but which create a novel and patentable invention when "arranged and combined together." ${ }^{36}$ Here, Laitram gained protection for its invention because it "combined ordinary elements in an extraordinary way-a novel

28. Id.

29. Id. at $195-97$.

30. Id. at 197.

31. See id.

32. Id. at 195.

33. Id. at 198.

34. See Deepsouth Packing Co. v. Laitram Corp., 406 U.S 518, 519 (1972).

35. See id. at 520 .

36. Id. at 520-21 (quoting Prouty v. Draper, Ruggles \& Co., 41 U.S. 336 (1842)). 
union of old means was designed to achieve new ends." ${ }^{37}$

The district court enjoined Deepsouth from making or using its machinery in the United States. ${ }^{38}$ Since the court prohibited Deepsouth from combining the components in the United States, the company sought to continue making the unprotectable components in the United States and then export them for assembly abroad. ${ }^{39}$ Deepsouth's conduct relied on a narrow interpretation of \271(a), which instructs that any entity that "makes ... any patented invention, within the United States," without authority, infringes the patent. ${ }^{40}$ As Deepsouth read the statute, as long as it did not assemble the unprotectable components in the United States, it did not "make" the invention in the United States and, therefore, it did not infringe on Laitram's patents. ${ }^{41}$ The district court found that Deepsouth's export for assembly abroad did not infringe, but the Court of Appeals for the Fifth Circuit reversed. The Supreme Court granted certiorari to determine whether Deepsouth could export from the United States the components of its machinery for assembly and sale abroad without infringing Laitram's U.S. patents. ${ }^{42}$

Laitram argued that only a "hypertechnical reading" of the Patent Act would allow Deepsouth to export components for assembly abroad. ${ }^{43}$ Such a "hypertechnical reading," Laitram claimed, would impinge on Laitram's patent rights. ${ }^{44}$ Laitram asserted that Deepsouth should be liable for infringement under $\int 271$ (a) because Deepsouth practically made the machinery in the United States and merely left the final step to be completed abroad. ${ }^{45}$ Laitram argued that the narrow interpretation of "make" used by Deepsouth was contrary to the language in the Constitution that originally authorized Congress to create patent laws "To promote the Progress of Science and useful Arts." 46

Justice White wrote the majority opinion, cautioning against expanding patent rights without a sign from Congress. ${ }^{47}$ Noting the importance of its decision for foreign trade, the Court determined that Laitram's "mere inference from ambiguous statutory language" was insufficient to be understood as a signal from Congress to ignore the presumption against

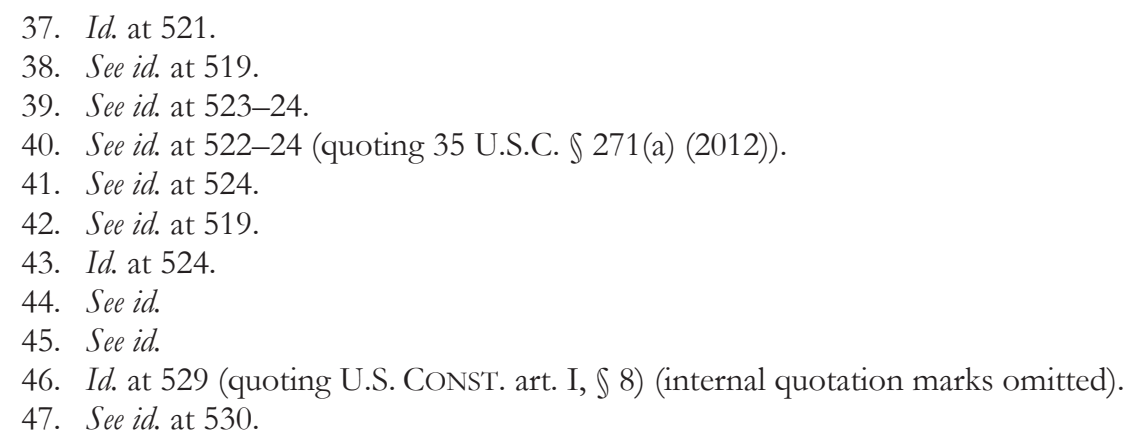


extraterritoriality and to expand the bounds of U.S. patent law. ${ }^{48}$ Instead, the Court contended that the language of \ 271 showed Congress's intent for U.S. inventors to seek protection abroad through foreign rather than U.S. patents. ${ }^{49}$ The Court concluded that the U.S. "patent system makes no claim to extraterritorial effect," and thus Deepsouth's assembly of components abroad did not infringe on Laitram's U.S. patents. ${ }^{50}$

\section{Filling the Gap: Patent LaW Amendments ACt of 1984}

In enacting 35 U.S.C. $\int 271(\mathrm{f})$ Congress intended to rebut the presumption against extraterritoriality and relied on the facts of Deepsouth to shape the exception. ${ }^{51}$ While Congress did not clearly define the scope of the statute, the origin of $\int 271(\mathrm{f})$ and its neighboring statutes inform the section's interpretation.

Judges, legislators, and commentators have described Deepsouth's evasion of infringement liability through extraterritorial assembly as the Deepsouth "loophole." 52 Deepsouth narrowly avoided infringement liability by saving the final step of assembly to be completed beyond the reach of U.S. patent law. ${ }^{53}$ Deepsouth was successful in doing so because the patented machinery was entirely made up of commodity components that were not protectable themselves. ${ }^{54}$ Therefore, it was not an infringement for Deepsouth to make those components in the United States and then ship them abroad for assembly and sale. ${ }^{55}$

Congress strengthened patent protection in the early 1980s in reaction to growing competition with foreign manufacturers and concern over lack of U.S. innovation, caused in part by legal loopholes like that exploited by Deepsouth. ${ }^{56}$ In 1984, Congress enacted 35 U.S.C. \271(f) in "response to the ... Deepsouth decision which interpreted the patent law not to make it

48. Id.

49. See id.

50. $I d$.

51. See S. REP. NO. 98-663, at 2-3 (1984).

52. See, e.g., Microsoft Corp. v. AT\&T Corp., 550 U.S. 437, 444 n. 3 (2007); Brief for Petitioners at 5, Life Techs. Corp. v. Promega Corp., 137 S. Ct. 734 (2017) (No. 14-1538), 2016 WL 4578846, at *5; Brief for Respondent at 27, Life Techs. Corp. v. Promega Corp., 137 S. Ct. 734 (2017) (No. 14-1538), 2016 WL 6216126, at *27; S. REP. No. 98-663, at 6 (1984); James R. Farrand, Territoriality and Incentives Under the Patent Laws: Overreaching Harms U.S. Economic and Technological Interests, 21 BERKELEY TECH. L.J. 1215, 1219 (2006); Timothy R. Holbrook, Extraterritoriality in U.S. Patent Law, 49 WM. \& MARY L. REV. 2119, 2127 (2008).

53. See Deepsouth, 406 U.S. at 524.

54. See id. at 520-22.

55. See id. at 524 .

56. Farrand, supra note 52, at 1225 n. 19 (discussing the pattern of relative strength of patent laws from the late 1920 s to the 1980 s). 
infringement where the final assembly and sale is abroad." 57 To close the Deepsouth loophole, the bill amended patent law to attach infringement liability for supplying components to make the invention abroad just as it would if "the invention [were] 'made' or 'sold' in the United States." ${ }^{\prime \prime}$ The new statute was needed to counteract Deepsouth's chilling effect on 'invention, innovation, and investment" in the United States. ${ }^{59}$

Section 271(f) creates infringement liability for a party that supplies, from the United States, "all or a substantial portion" of components of a patented invention for overseas assembly that would constitute infringement if it had occurred within the United States. ${ }^{60}$ Furthermore, the statute creates liability for a party that exports any component specifically made for use in a patented invention for overseas assembly that would constitute infringement if it had occurred within the United States. ${ }^{61}$

The surrounding "statutory scheme" ${ }^{\text {" }}$ offers guidance for interpreting the two main elements of $\int 271(\mathrm{f})$ : (1) the supply of components abroad; and (2) the intent to act in such a way that would constitute infringement in the United States. Comparison to $\int 271$ (a) shows Congress's clear choice to expand the reach of patent law extraterritorially, whereas $\iint 271(\mathrm{~b})$ and (c) provide the basis for understanding the role of intent in $\int 271(\mathrm{f})$.

The extraterritorial bounds of $\int 271(\mathrm{f})$ are the inverse of the territorial bounds set by $\$ 271(\mathrm{a})$. While the culpable infringer under $\int 271(\mathrm{f})$ must have supplied components "in or from the United States," therefore grounding its actions within the U.S. borders, it is liable for activity that occurs outside the U.S. borders. ${ }^{63}$ However, $\int 271$ (a) classifies infringement as the trespass of another's patent rights "within the United States or [the] import[] into the United States [of] any patented invention." ${ }^{\prime 4}$ Section 271(f) is meant to apply to activity not covered by $\int 271$ (a) — the combination of supplied components "outside of the United States." ${ }^{65}$ The Supreme Court's narrow interpretation of $\int 271$ (a) in Deepsouth did not bind courts interpreting the different statutory provisions of $\int 271(\mathrm{f})$, although the Court's method in Deepsouth is still relevant

57. S. REP. No. 98-663, at 2-3 (1984) ("Permitting the subterfuge which is allowed under the Deepsouth interpretation of the patent law weakens confidence in patents among businesses and inventors.").

58. Id. at 3 .

59. Id.

60. 35 U.S.C. \ 271(f)(1) (2012); see also supra note 8.

61. See 35 U.S.C. \271(f)(2) (2012); see also supra note 8.

62. United Sav. Ass'n v. Timbers of Inwood Forest Assocs., 484 U.S. 365, 371 (1988).

63. See 35 U.S.C. \271(f) (2012).

64. 35 U.S.C. $\$ 271$ (a) (2012).

65. 35 U.S.C. $\int 271(\mathrm{f})(2012)$. 
to the inquiry. ${ }^{66}$

The indirect infringement statutes inform the interpretation of the intent requirement in $\int 271(\mathrm{f})$, which Congress did not otherwise detail. While $\int 271(\mathrm{f})$ is unique in that it applies indirect infringement liability where there has been no direct infringement, ${ }^{67}$ it borrows language from the inducement and contributory infringement statutes. ${ }^{68}$ The language of $\int 271(\mathrm{f})(1)$ borrows the term "active inducement" from $\ 271(\mathrm{~b})$, which states: "Whoever actively induces infringement of a patent shall be liable as an infringer." ${ }^{\prime 69}$ Similarly, $\int 271(\mathrm{f})(2)$ imports the knowledge element from the contributory infringement statute, $\int 271(\mathrm{c})$, requiring that the infringer know it supplied a component specially made for a patented invention. ${ }^{70}$ Both $\iint 271(\mathrm{~b})$ and (c) require that the indirect infringer know that its actions allow for direct patent infringement. ${ }^{71}$ Further, inducement under $\int 271(\mathrm{~b})$ requires affirmative action to achieve a desired, infringing result. ${ }^{72}$ Since Congress wrote $\int 271(\mathrm{f})(1)$ based on $\int 271(\mathrm{~b}){ }^{73}$ the notions of knowledge and intent in $\int 271(\mathrm{~b})$ inducement

66. See Deepsouth Packing Co. v. Laitram Corp., 406 U.S 518, 527-28 (1972).

67. See 35 U.S.C. \271(f) (2012). Indirect infringement occurs when an accused party "falls short of practicing every single element of a claimed invention," but "acted with some measure of intentionality or scienter." Robert P. Merges, A Few Kind Words for Absolute Infringement Liability in Patent Law, 31 BERKELEY TECH. L.J. 1, 3 n.1 (2016). Generally, indirect infringement requires direct infringement — that is, infringement under $\int 271$ (a). See Limelight Networks, Inc. v. Akamai Techs., Inc., 134 S. Ct. 2111, 2117-18 (2014) (stating that "liability for inducement must be predicated on direct infringement" and that a party "cannot be liable for inducing infringement that never came to pass"). However, in $\ 271(\mathrm{f})$ there can be no direct infringement as the actions that would be directly infringing (the combination of components) happen outside the United States and are therefore out of the reach of $\int 271$ (a). See Aro Mfg. Co. v. Convertible Top Replacement Co., 365 U.S. 336, 341 (1961); Limelight Networks, 134 S. Ct. at 2117. 5828.

68. 130 CONG. REC. H10,525 (daily ed. Oct. 1, 1984), reprinted in 1984 U.S.C.C.A.N 5827,

69. 35 U.S.C. $\$ 271(b)(2012)$.

70. 35 U.S.C. $\int 271(\mathrm{c})(2012)$ states:

Whoever offers to sell or sells within the United States or imports into the United States a component of a patented machine, manufacture, combination or composition, or a material or apparatus for use in practicing a patented process, constituting a material part of the invention, knowing the same to be especially made or especially adapted for use in an infringement of such patent, and not a staple article or commodity of commerce suitable for substantial noninfringing use, shall be liable as a contributory infringer.

See also Aro, 365 U.S. at 488.

71. See 35 U.S.C. SS 271(b)-(c) (2012); Global-Tech Appliances, Inc. v. SEB S.A., 563 U.S. 754, 765-66 (2011) (holding that contributory infringement under \271(c) and induced infringement under $\int 271$ (b) require knowledge of the patent infringement).

72. See Global-Tech, 563 U.S. at 760.

73. See 130 CONG. REC. H10,525 (daily ed. Oct. 1, 1984), reprinted in 1984 U.S.C.C.A.N 
provide a framework for interpreting the meaning of inducement in \271(f)(1). Similarly, the scienter requirements of \271(c) inform the meaning of $\int 271(\mathrm{f})(2) .^{74}$ Thus, these related patent infringement statutes provide a basis for courts and practitioners to interpret $\int 271(\mathrm{f})$ where Congress has not fully articulated its scope.

D. INTERPRETING S 271(f): MICROSOFT V. AT\&T

The Supreme Court interpreted $\ 271(\mathrm{f})$ in Microsoft v. AT\&T. In that case, AT\&T sued Microsoft for infringement of a patent protecting an apparatus to digitally encode and compress recorded speech. ${ }^{75}$ AT\&T claimed that Microsoft's Windows operating system infringed on this patent because it could process speech in the same manner as AT\&T's patent. ${ }^{76}$

Microsoft sold its Windows operating system to foreign computer manufacturers to install onto the computers they sold. ${ }^{77}$ To do so, Microsoft sent a master version of the Windows software, via disk or electronic transmission, from the United States to the foreign manufacturers, which generated copies from the master version. ${ }^{78}$ For this reason, AT\&T sued under $\int 271(\mathrm{f})(1)$, claiming that Microsoft effectively "supplie[d] . . from the United States" a component of its patented invention. ${ }^{79}$

Microsoft responded to AT\&T's $\ 271(\mathrm{f})(1)$ claim by arguing that the uninstalled software was not a "component" of the patented speech processor because it was intangible in its uninstalled form. ${ }^{80}$ Further, Microsoft contended that, even if the software in abstract form was considered to be a component, the copies of Windows made abroad were not "supplie[d] ... from the United States." 81

The Federal Circuit expanded the extraterritorial reach of patent law by finding Microsoft liable for $\int 271(f)(1)$ infringement, attributing its decision to congressional intent. ${ }^{82}$ However, the Supreme Court reversed and found Microsoft's actions non-infringing under $\ 271(\mathrm{f})(1)$, limiting the scope of the statute. ${ }^{83}$ The Court determined that software in the abstract is "an idea without physical embodiment" and that it cannot be a component amenable

$5827,5828$.

74. See id.

75. See Microsoft Corp. v. AT\&T Corp., 550 U.S. 437, 441 (2007).

76. See id. at 441-42.

77. See id. at 445 .

78. See id.

79. Id. at 446-47 (internal quotation marks omitted) (quoting 35 U.S.C. $\$ 271(\mathrm{f})(2012)$ ).

80. Id. at 447.

81. Id. (internal quotation marks omitted) (quoting 35 U.S.C. $\$ 271(\mathrm{f})(2012)$ ).

82. See AT\&T Corp. v. Microsoft Corp., 414 F.3d 1366, 1371-72 (Fed. Cir. 2005).

83. See Microsoft, 550 U.S. at 447. 
to combination until a user or manufacturer copies, installs, and runs it on a computer. ${ }^{84}$ Justice Ginsburg's opinion for the Court held that infringement could only occur when a user or manufacturer installed Windows on a computer, enabling the computer to perform the patented speech manipulation. ${ }^{85}$ Further, the Court noted that the manufacturers abroad installed Windows software on the computers by making copies of a master version and that those installed copies "were not themselves supplied from the United States." 86 Thus, because Windows software in abstract form was not a component, and because the copies of Windows installed on the foreign computers were not supplied from the United States, the Court held that Microsoft was not liable under $\int 271(\mathrm{f})(1) .{ }^{87}$

To reach its conclusion, the Supreme Court discussed the application of the presumption against extraterritoriality to $\ 271(\mathrm{f})$. The Court decided that the presumption against extraterritoriality quieted any doubts that Microsoft's actions were not covered by $\int 271(\mathrm{f})(1)$ because "United States law . . . does not rule the world." "Recognizing that $\int 271(\mathrm{f})$ is an exception to the general rule that our patent law does not apply extraterritorially," the Court "resist[ed] giving the language in which Congress cast $\int 271(\mathrm{f})$ an expansive interpretation." 89 Echoing Deepsouth, the Court stated that AT\&T should obtain and enforce foreign patents to prevent copying abroad rather than asking the Court to expand the reach of United States patent law beyond what was intended by Congress in $\$ 271(\mathrm{f})(1) .^{90}$

In its conclusion, the Court stated that Congress was the proper institution to amend the scope of patent law, and not the "Judiciary forecasting Congress'[s] likely disposition." 91 Nearly a decade later, Congress had not acted, and the Court took another opportunity to consider \271(f) in Life Technologies $v$. Promega.

\section{LIFE TECHNOLOGIES V. PROMEGA}

A. FACTS

In Life Technologies v. Promega, Promega sued Life Technologies for infringement of its U.S. Patent No. RE 37,984 (the Tautz patent). ${ }^{92}$ The patent

84. Id. at 449-52.

85. See id. at 442 .

86. Id. at 453 .

87. See id. at 454.

88. Id. at $454-55$.

89. Id. at 442.

90. See id. at 456 .

91. Id. at 458-59.

92. See Life Techs. Corp. v. Promega Corp., 137 S. Ct. 734, 738 (2017). 
claims a genetic testing toolkit used to "amplify" deoxyribonucleic acid (DNA) by making many copies of a specific nucleotide sequence from small samples of genetic material. ${ }^{93}$ The patent protects a combination of five components: "(1) a mixture of primers that mark the part of the DNA strand to be copied; (2) nucleotides for forming replicated strands of DNA; (3) an enzyme known as Taq polymerase; (4) a buffer solution for the amplification; and (5) control DNA." $" 94$

Promega was the exclusive licensee of the Tautz patent, and it sublicensed the patent to Life Technologies, which manufactured and sold the kits in certain law enforcement fields allowed by the license. ${ }^{95}$ Life Technologies eventually began to sell the kits outside of the specific fields delineated in the license agreement, namely for use in clinical and research markets worldwide. ${ }^{96}$ Evidence and testimony presented at trial suggested that Life Technologies violated the license knowingly. ${ }^{97}$

Life Technologies manufactured four out of the five kit components in the United Kingdom. ${ }^{98}$ However, Life Technologies manufactured the fifth component, Taq polymerase, in the United States, which it then shipped to its United Kingdom facilities to be combined with the other components. ${ }^{99}$ Promega sued Life Technologies for patent infringement under $\$ 271(\mathrm{f})(1)$, claiming that infringement liability arose from the supply of Taq polymerase from the United States. ${ }^{100}$

\section{B. Procedural History}

In an expansive opinion, the Federal Circuit held that Life Technologies was liable for infringement under $\int 271(\mathrm{f})(1)$ for supplying a single component for combination abroad. ${ }^{101}$

Turning first to an analysis of the language of $\int 271(f)(1)$, the court

\footnotetext{
93. Id.

94. Id.

95. See id.

96. See id.

97. See Brief for Plaintiff-Cross Appellant at 16-19, Promega Corp. v. Life Techs. Corp., 773 F.3d 1338 (Fed. Cir. 2014) (Nos. 2013-1011, 2013-1029, 2013-1376), 2013 WL 4812402, at $* 16-18$.

98. See Life Techs., 137 S. Ct. at 738.

99. See id.

100. See id.

101. Life Techs., 773 F.3d at 1341, rev'd and remanded, 137 S. Ct. 734 (2017). This holding reversed Western District of Wisconsin's ruling that the supply of a single component was not sufficient for liability under $\ 271(f)(1)$ and inducement required involvement of a third party. Promega Corp. v. Life Techs. Corp., No. 10-cv-281-bbc, 2012 WL 12862829, at *6-8 (W.D. Wis. Sept. 13, 2012), aff'd in part, vacated in part, rev'd in part, 773 F.3d 1338 (Fed. Cir. 2014), rev'd and remanded, 137 S. Ct. 734 (2017), and aff'd, 875 F.3d 651 (Fed. Cir. 2017).
} 
reasoned that ordinary, dictionary definitions of both "substantial" and "portion" do not imply a specific quantity. ${ }^{102}$ Instead, the court interpreted the phrase "substantial portion" to suggest that "a single important or essential component can be a 'substantial portion of the components' of a patented invention." "103 The court rejected Life Technologies' argument that, by referring to "components" plural, the statute required more than one component to be supplied abroad for the statute to apply. ${ }^{104}$ The court asserted that "components" plural referred to all the components of the patented invention, not merely the component or components supplied. ${ }^{105}$ Additionally, the court stated that the comparison of \271(f)(1) with \271(f)(2) was inappropriate as the separate provisions are applied in different contexts and the language of $\int 271(\mathrm{f})(2)$ "does not control" that of $\int 271(\mathrm{f})(1) .{ }^{106}$

The court applied its qualitative definition of "substantial portion" and reasoned that the kits would be non-functional without Taq polymerase as it was essential to the process of DNA amplification. ${ }^{107}$ Therefore, the court concluded that Taq polymerase was one of the principal components of the kit. ${ }^{108}$ Following this reasoning, the court found the single component of Taq polymerase to be a "substantial portion" of the patented invention, and therefore within the scope of $\int 271(\mathrm{f})(1) .{ }^{109}$

The Federal Circuit also reversed the district court's holding that inducement required the involvement of a third party. ${ }^{110}$ Instead of looking to the parallel language of $\$ 271(\mathrm{~b})$, the court turned to the definition of "inducement" and found that a broad understanding of the word means: "to bring about, to cause." "111 The court pointed out that the term in the statute was directed at "the combination," not a person or entity. ${ }^{112}$ If Congress had intended to include a third-party actor, the court reasoned, it could have indicated the inducement of "another" in the statute. ${ }^{113}$

Life Technologies petitioned for a writ of certiorari on two questions:

1. Whether the Federal Circuit erred in holding that a single entity can "actively induce" itself to infringe a patent under 35 U.S.C.

102. See id. at 1353.

103. $I d$.

104. See id. at 1354.

105. See id.

106. Id.

107. See id. at 1356.

108. See id.

109. See id.

110. See id. at 1351.

111. Id.

112. See id.

113. See id. 
$\int 271(\mathrm{f})(1)$.

2. Whether the Federal Circuit erred in holding that supplying a single, commodity component of a multi-component invention from the United States is an infringing act under 35 U.S.C. $\int 271(\mathrm{f})(1)$, exposing the manufacturer to liability for all worldwide sales. ${ }^{114}$

The Supreme Court granted certiorari only for the second question, declining to analyze the meaning of inducement under $\int 271(f)(1){ }^{115}$

\section{The Supreme Court Decision}

The Supreme Court granted certiorari to untangle the meaning of "substantial portion" and how to measure it. In the majority opinion written by Justice Sotomayor, ${ }^{116}$ the Court resolved that "substantial portion" implied a quantitative, not qualitative, measurement. ${ }^{117}$ The Court reasoned that the language surrounding the phrase "substantial portion" conveyed a "quantitative meaning." "118 Further, the Court reasoned that a qualitative or "case-specific" approach would be ineffective and ambiguous. ${ }^{119}$ Such an approach would only complicate the analysis by leaving it to juries to interpret. ${ }^{120}$ Also, a qualitative approach, like the one presented by the Federal Circuit, would be unproductive because it would rely on the "importance" of components to the patented invention. ${ }^{121}$ Few, if any, components of multicomponent inventions are unimportant or unnecessary for the function of the invention, and so, any component could invoke liability under a qualitative interpretation of the statute. ${ }^{122}$ Thus, the Court concluded that a "quantitative interpretation hews most closely to the text of the statute and provides an administrable construction." 123

114. Petition for Certiorari at i, Life Techs. Corp. v. Promega Corp., 137 S. Ct. 734 (2017) (No. 14-1538), 2015 WL 3941490, at *i.

115. See Life Techs. Corp. v. Promega Corp., 137 S. Ct. 734, 737 (2017) (“We granted certiorari to determine whether a party that supplies a single component of a multicomponent invention for manufacture abroad can be held liable for infringement under $\left.\int 271(\mathrm{f})(1) . "\right)$.

116. Justice Sotomayor was joined by Justices Kennedy, Ginsburg, Breyer, and Kagan. Justices Thomas and Alito joined as to all but Part II-C. Justice Alito filed an opinion concurring in part and concurring in the judgment, in which Justice Thomas joined. Chief Justice Roberts did not participate in the decision.

117. See id. at 739 .

118. Id. at 740 .

119. See id.

120. See id.

121. See id. at 741.

122. See id.

123. Id. 
Having resolved that a quantitative approach was appropriate, the Court turned to the statutory text to determine whether a single component could be a "substantial portion" and create liability under $\int 271(\mathrm{f})(1) \cdot{ }^{124}$ Similar to the district court's reasoning, the Supreme Court compared the language of $\int 271(\mathrm{f})(1)$ to that of $\int 271(\mathrm{f})(2)$ to hold that a single component is not sufficient to trigger $\int 271(\mathrm{f})(1)$ liability. ${ }^{125}$ The Court noted that " $\int 271(\mathrm{f})(1)$ refers to 'components,' plural, [but] \271(f)(2) refers to 'any component,' singular." 126 The Court reasoned that reading them in this way, where \271(f)(1) refers to more than one component and $\int 271(\mathrm{f})(2)$ refers to a single component, allows the provisions to "work in tandem." 127

The Court also looked to the history of $\int 271(\mathrm{f}) .{ }^{128}$ The Court determined that its interpretation of the statute comported with Congress's intent: fix the Deepsouth loophole and expand the reach of patent laws to components of a patented invention manufactured in the United States but assembled overseas. ${ }^{129}$ However, the Court concluded that a single component exported for assembly abroad "is outside the scope of the statute" because it is not "all or a substantial portion of the components" as Congress intended for $\$ 271(\mathrm{f})$ infringement liability to apply. ${ }^{130}$

In his concurrence, Justice Alito, joined by Justice Thomas, disagreed that Congress simply wanted to close the Deepsouth loophole. ${ }^{131}$ He suggested that Congress wanted to go further, but stated that how much further was not determinable from the origins of $\int 271(\mathrm{f})$; the legislative history is not substantial enough to properly infer Congress's intent. ${ }^{132}$ Justice Alito also highlighted that the majority's opinion simply held that a single component was not a "substantial portion" of a patented invention's components, but did not say how many more components were necessary to constitute a "substantial portion." 133

In conclusion, the Court's quantitative interpretation of "substantial portion" informed the holding that a single component of a multicomponent patent could not be a "substantial portion of the components" and that its

124. See id.

125. See id. at 742 (interpreting $\int 271(f)(1)$ in light of $\int$ 271(f)(2)); Promega Corp. v. Life Techs. Corp., No. 10-cv-281-bbc, 2012 WL 12862829, at *6-8 (W.D. Wis. Sept. 13, 2012) (similarly interpreting $\mathbb{S} 271(\mathrm{f})(1)$ in light of $\int 271(\mathrm{f})(2)$ ).

126. Life Techs., 137 S. Ct. at 742.

127. Id. at $741-42$.

128. See id. at 742 .

129. See id. at 742-43; see also supra Section II.C

130. Life Techs., $137 \mathrm{~S}$. Ct. at 743; see also supra note 8.

131. See id. (Alito, J. concurring).

132. See id.

133. See id. 
supply is not an infringing act under $\int 271(\mathrm{f})(1) \cdot{ }^{134}$ Therefore, the Court found that the supply of Taq polymerase from the United States did not trigger $\int 271(\mathrm{f})(1)$ infringement liability. ${ }^{135}$ Put simply, one is not enough.

\section{WHAT DID THE COURT DO?}

The Supreme Court's opinion in Life Technologies is brief and may be unsatisfactory to those looking for substantial guidance on interpreting the statute. ${ }^{136}$ In an attempt to clarify the ambiguity surrounding $\int 271(\mathrm{f})(1)$ and "not to compound it," the Court simply instructed that the supply of more than one component is necessary for liability to attach under the provision. ${ }^{137}$ While patent owners, competitors, and the attorneys that represent them may find the Court's opinion unsatisfactorily meager in guiding their practice, the Life Technologies decision was sufficient to block an overreaching interpretation and application of the statute in the future. The Court's minimal ruling stifled

134. Id. at 743 .

135. See id. at $737-38$.

136. An unscientific survey of various online sources, including law firm blogs, revealed dissatisfaction with the Supreme Court's lack of direction among those choosing to comment about the case. See, e.g., John Duffy, Opinion Analysis: A "Substantial Portion of the Components" Means "More Than One Component", SCOTUSBLOG (Feb. 23, 2017), http:// www.scotusblog.com/2017/02/opinion-analysis-substantial-portion-components-means -one-component [https://perma.cc/4SKR-NB3K]; Life Technologies Corp. v. Promega Corp.: Supreme Court Holds That Infringement Under 35 U.S.C. $\int 271(f)(1)$ Requires Providing More Than One Component of an Invention, Sullivan \& CROMWELL LLP (Feb. 23, 2017), https://www.sullcrom.com/siteFiles/Publications/SC_Publication_Life_Technologies_Cor p_v_Promega_Corp.pdf [http://perma.cc/27qa-P4UR]; Katya Ascher, Quantity Not Quality: Patent Infringement by Components Exported from the US Is a Game of Numbers, LEXOLOGY (May 31, 2017), https://www.lexology.com/library/detail.aspx?g=02095c15-97dc-4b69-9da4e65b064adc55 [https://perma.cc/Q4HV-JRRL]; Clifford Ragsdale Lamar, High Court's Patent Guidance on Exporting Component Parts, LAW360 (Feb. 27, 2017), https://www.law360.com/ articles/895954/high-court-s-patent-guidance-on-exporting-component-parts [https:// perma.cc/7BDL-YEF2]; Brenden S. Gingrich \& Jeffrey C. Wu, Life Technologies Corp. v. Promega Corp.: Supreme Court Limits Infringement Liability for Suppliers Under \ 271(f)(1), KNOBBE MARTENS (Mar. 8, 2017), https://www.knobbe.com/news/2017/03/life-technologies-corpv-promega-corp-supreme-court-limits-patent-infringement [https://perma.cc/RVM63HAN]; Tania Uren \& Gavin Recchia, U.S. Supreme Court Clarifies Extraterritorial Reach of U.S. Patents, LeXology (April 24, 2017), https://www.lexology.com/library/detail.aspx?g=ee0da 762-e5bf-4922-808c-99fbb21 f81bd [https:/ / perma.cc/3BLS-PRZ9]; Brinks, Gilson, \& Lione, Supreme Court Rules That Patent Infringement Liability Based on Supply of "A Substantial Portion" of the Components of an Invention Manufactured Abroad Requires More Than the Supply of a Single Commodity Component of the Invention, BRINKS GILSON \& LIONE (Mar. 3, 2017), http:// www.brinksgilson.com/supreme-court-rules-that-patent-infringement-liability-based-onsupply-of-a-substantial-portion-of-the-components-of-an-invention-manufactured-abroadrequires-more-than-the-supply-of-a-single-com [https://perma.cc/ZSC6-52FG].

137. Life Techs., 137 S. Ct. at 740. 
the Federal Circuit's expansive interpretation of $\int 271(\mathrm{f})$ and reopened the provision for further interpretation by lower courts or direct amendment by Congress. The Supreme Court's decision allows lower courts enough flexibility to work through the statute until the Court is ready to rule again, or Congress clarifies the law. By saying seemingly very little, the Supreme Court's decision is significant.

\section{A. “One Is Not EnOugh” Is EnOugh For the COurT \\ 1. The Life Technologies Decision Left Room for Interpretation}

The Court's opinion does not thoroughly interpret the meaning of "substantial portion of the components" under the statute, but the opinion creates the opportunity for lower courts to construe the scope of the statute. ${ }^{138}$

Life Technologies only provides that a substantial portion is less than all of the components, but more than one component. As highlighted in Justice Alito's concurrence, there is no indication as to how many more components are necessary to make a substantial portion. ${ }^{139}$ The majority's analysis, focusing on whether the words are singular or plural, does not offer any guidance.

This sparse opinion allows lower courts to explore the different scenarios that may affect how a "substantial portion" is quantified. For example, some multi-component patents include only two components, ${ }^{140}$ while others can have many more. Lower courts will have the opportunity to determine if a substantial portion of components for a five-component patent is similar to that of a fifty-component patent. Lower courts may also have the opportunity to address the issue presented by a two-component invention: where a single component is not enough, but two components are all, what constitutes a "substantial portion"?

Further, because the parties agreed that the Tautz patent contained five components, the Court did not define "component" under $\int 271(\mathrm{f}) .{ }^{141}$ This analysis will be important for lower courts to address; as the Life Technologies decision determined that a "substantial portion" is meant to be interpreted quantitatively, parties will need to know how to count their components. ${ }^{142}$ The Supreme Court properly declined to opine on the interpretation of "component" in dicta, but rather allowed the district courts to grapple with the issue in the first instance.

The Supreme Court also declined to grant certiorari on the issue of the

138. See supra note 136; infra Section IV.B.2.

139. See Life Techs., 137 S. Ct. at 743 (Alito, J. concurring).

140. See U.S. Patent No. 3,870,675 A (issued Mar. 11, 1975).

141. See Life Techs., 137 S. Ct. at 738. In Microsoft the Court held that a component must be tangible. See Microsoft Corp. v. AT\&T Corp., 550 U.S. 437, 451-52 (2007).

142. See Life Techs., 137 S. Ct. at 741. 
inducement requirement of $\int 271(\mathrm{f})(1)$ and left the Federal Circuit's opinion in place to either be precedential or challenged. The inducement requirement of the provision adds an analysis of the mindset and purpose of the actor supplying components. The Federal Circuit found that a third party was not necessary for "active inducement" and that a party could, in effect, induce itself. ${ }^{143}$ This is an uncommon interpretation of inducement. Usually, inducement relies on a third-party actor - to be liable for inducement, a party must induce another to infringe a patent. ${ }^{144}$ By allowing a single party to be liable for "active inducement," the Federal Circuit's decision broadened the application of $\int 271(f)(1)$.

The Federal Circuit's opinion that a party can 'induce itself" is expansive and unconventional, but compatible with the notions of knowledge and intent that $\int 271(\mathrm{f})$ implies. A party that is capable of inducing itself likely has knowledge of its actions and acts with intent. The concept of inducing oneself is absent from $\int 271$ (b) analysis because if a party were both to induce infringement and to directly infringe, it would already be liable for direct infringement under $\int 271$ (a). However, because direct infringement under \271(a) is inapplicable where the components of a patented invention are combined and sold abroad, Life Technologies addressed the unique question of whether a U.S. manufacturer may be liable for inducing infringement through its own foreign facilities. In denying certiorari to determine whether a party can induce itself under $\int 271(\mathrm{f})(1)$, the Court did not address the Federal Circuit's novel ruling or the extent to which knowledge and intent affect the infringement analysis. ${ }^{145}$ Instead, the Court's opinion allows the Federal Circuit to act within the restraints of stare decisis if it finds that its ruling has had ill effects in the district courts.

\section{An Obscure Statute with Big Implications: Careful Interpretation Is Paramount}

Section $271(\mathrm{f})$ is a relatively specific statute, enacted in response to a specific fact pattern. ${ }^{146}$ While its world of application may be smaller than that of other statutes, it can have significant implications. Because of this, it is extremely important that courts interpret and apply the statute correctly, and the Supreme Court was right to decline to issue an advisory opinion.

As discussed above, Congress wrote $\int 271(\mathrm{f})$ as an exception to the

143. See Promega Corp. v. Life Techs. Corp., 773 F.3d 1338, 1351-53 (Fed. Cir. 2014), rev'd and remanded, 137 S. Ct. 734 (2017).

144. See Petition for Certiorari at 13-15, Life Techs. Corp. v. Promega Corp., 137 S. Ct. 734 (2017) (No. 14-1538), 2015 WL 3941490, at*13-15.

145. See Life Techs., 773 F.3d at 1351-53; see also Life Techs., 137 S. Ct. at 737-39.

146. See S. REP. NO. 98-663, at 3 (1984) (noting the bill's intention to remedy the "subterfuge ... allowed under the Deepsouth interpretation"). 
longstanding presumption against extraterritoriality. ${ }^{147}$ The presumption has a long history in patent law, and the Supreme Court has been hesitant to expand the reach of patent law beyond the United States' borders, even when the statute arguably allows it to do so. ${ }^{148}$ The Court does not take the presumption against extraterritoriality lightly and has recently exercised it to "resist giving ... \271(f) an expansive interpretation."149

The application of $\int 271(\mathrm{f})$ can also have impressive monetary implications. Damages analysis may include worldwide sales figures because the statute attaches infringement liability for activity that happens abroad. In Life Technologies, a jury awarded Promega over $\$ 50$ million in lost profits on worldwide sales of the infringing kits. ${ }^{150}$ Regardless of the Supreme Court's decision in Life Technologies, foreign manufacturers that do not source products from the United States are always safe from \271(f) liability. ${ }^{151}$ As such, manufacturers may choose to move their facilities abroad to avoid triggering immense damages based on worldwide sales. ${ }^{152}$ When patent damages are not limited to U.S. sales, there are much higher stakes for infringement liability. ${ }^{153}$ Thus, proper interpretation of the statute is crucial. The Court in Life Technologies showed proper judicial restraint in declining to issue an advisory opinion on $\int 271(\mathrm{f})$ since the statute purposefully pushes the boundaries of patent law and can inflate damage awards to a global scale.

147. See supra Section II.C.

148. See Microsoft Corp. v. AT\&T Corp., 550 U.S. 437, 442 (2007).

149. Id.

150. The district court vacated this award, but it was then reinstated by the Federal Circuit, and then once again vacated by the Supreme Court's opinion and the subsequent Federal Circuit decision. See Promega Corp. v. Life Techs. Corp., No. 10-cv-281-bbc, 2012 WL 12862829, at*1-2 (W.D. Wis. Sept. 13, 2012), aff'd in part, vacated in part, rev'd in part, 773 F.3d 1338 (Fed. Cir. 2014), rev'd and remanded, 137 S. Ct. 734 (2017), and aff'd, 875 F.3d 651 (Fed. Cir. 2017).

151. See Sean B. Fernandes, Microsoft Corp. v. AT\&T: A Welcome Return to Patent Law's Tradition of Territoriality, 23 BERKELEY TECH. L.J. 75, 101 (2008) (discussing the potential disincentives of $\int 271(\mathrm{f})$ and the irony of a "statute intended for the protection of U.S. manufacturing" being "used to discriminate against domestic producers").

152. See Donald S. Chisum, Normative and Empirical Territoriality in Intellectual Property: Lessons from Patent Law, 37 VA. J. INT’L L. 603, 607-08 (1997).

153. In WesternGeco v. ION Geophysical, the Federal Circuit ruled that profits lost on sales outside the United States for combinations infringing under $\int 271(\mathrm{f})$ were unavailable as a matter of law. See WesternGeco L.L.C. v. ION Geophysical Corp., 791 F.3d 1340, 1351 (Fed. Cir. 2015), cert. granted, judgment vacated sub nom. WesternGeco LLC. v. ION Geophysical Corp., 136 S. Ct. 2486 (2016). WesternGeco has petitioned for certiorari on this issue. If the Federal Circuit's holding stands, the significance of damages will be lessened in $\ 271(\mathrm{f})$ implications. See Petition for Certiorari, WesternGeco L.L.C. v. ION Geophysical Corp., 837 F.3d 1358 (Fed. Cir. 2016) (15-1085), 2016 WL 792196. 


\section{A Proportional Method for Defining "Substantial Portion"}

The Supreme Court's opinion in Life Technologies may be unsatisfactory for practitioners because it did not provide guidance as to how many more than one component constitutes a "substantial portion," and it did not discuss how factors of knowledge and intent influence this analysis. ${ }^{154}$ However, the Supreme Court was right to decline to issue an advisory opinion detailing a method of interpretation. There are many complex factors at issue that make a single test difficult to formulate. For example, the Court could have provided a proportional test, which would have given practitioners and judges greater guidance, but also would have raised substantial problems of its own.

A seemingly simple solution, the Court could have imposed a proportional test to analyze how many components are necessary for a "substantial portion." Doing so would have still rejected the Federal Circuit's qualitative test but would have also addressed problems created by the Supreme Court's proposition that a single component was not sufficient. ${ }^{155}$ Specifically, a proportional test would resolve the complications posed by a simple numeric minimum, which creates inequalities because combination patents use different numbers of components. For example, if there had been only two components in the patent at issue in Life Technologies, would the Court still have reasoned that one component was not a "substantial portion"? The Court's "one is not enough" logic would suggest that \271(f)(1) cannot apply although this would be fifty-percent of the invention. ${ }^{156}$ And yet, the holding would not prevent a patentee from arguing for liability based on the supply of two components of a hundred-component product, although this would be a mere two-percent of the components. A proportional test would eliminate this discrepancy, as the set proportion would be equal among inventions regardless of the number of components.

To determine a reasonable proportion, the Court could have looked to $\int 271(\mathrm{f})$ 's history. Although the statutory history is limited, as Justice Alito noted, it is clear and direct. ${ }^{157}$ Section 271(f) resulted from the Court's Deepsouth decision, as Congress was worried that others could abuse the loophole Deepsouth identified and exploited. ${ }^{158}$ In that case, Deepsouth manufactured all of the components in the United States and supplied all of those components abroad for combination. Understandably, this is the origin of the "all ... components" language in \271(f)(1). However, Congress wrote

154. See supra note 136.

155. See supra Section IV.A.

156. See supra Section IV.A.

157. See Life Techs. Corp. v. Promega Corp., 137 S. Ct. 734, 743 (2017) (Alito, J. concurring).

158. See S. REP. NO. 98-663, at 3 (1984). 
\271(f)(1) to apply beyond the specific facts of Deepsouth by including "a substantial portion" as well. ${ }^{159}$ Congress could have meant to stay close to the idea that a culpable party would make or effectively make the patent, and therefore supply all or substantially all of the components. ${ }^{160}$

When it included "all or a substantial portion" in the statutory language, Congress loosened the grasp of the Court's "hypertechnical reading of the patent code" that let actors with bad intent and knowledge of their actions pass without liability. ${ }^{161}$ Because of this, a reasonable measure by which to understand "substantial portion" might look to the alleged infringer's intent. But using a quantitative assessment for a qualitative concept, such as intent, is inherently flawed. What proportion of components of an invention must be supplied to indicate that the supplier knows that its actions are effectively circumventing U.S. patent law? What proportion of components of a patented invention must an infringer supply such that the action is tantamount to making the invention in the United States and then exporting it?

Divining the proper proportion is itself a problematic task, but even if courts could settle on a proportion, applying any threshold raises additional issues. As the actors in Deepsouth displayed, if there is a cut-off for infringing action, actions one step below that cut-off will be non-infringing. This is the problem with defining infringement only as "making" or "supplying . . . all" of the components_one less than "all" evades liability. This may be why Congress chose to add "or a substantial portion" for $\int 271(\mathrm{f})(1)$ infringement, to make the provision more ambiguous and therefore more difficult to dodge. A numeric definition of "substantial portion" creates a similar cutoff, allowing bad actors to supply one component fewer to avoid liability. As soon as the bounds of $\int 271(f)(1)$ are defined, the statute becomes evadable. ${ }^{162}$ A simple

159. See Timothy R. Holbrook, Boundaries, Extraterritoriality, and Patent Infringement Damages, 92 NotRe DAME L. REV. 1745, 1754 (2017) (“The language of 'a substantial portion' broadens $\int 271(\mathrm{f})(1)$ beyond the facts of Deepsouth.").

160. The Court could also have looked to interpretations of phrases similar to "substantial portion" in other statutes, like "substantially all." For example, in 1990 the Seventh Circuit held that "substantially all" meant eighty-five percent in a statute regulating trucker's pension funds. Cont'l Can Co. v. Chi. Truck Drivers, Helpers \& Warehouse Workers Union (Indep.) Pension Fund, 916 F.2d 1154, 1160 (7th Cir. 1990). The Seventh Circuit said that "substantially all" was a legal term of art that Congress uses regularly, particularly in tax statutes. See id. In fact, some of the Supreme Court Justices repeatedly misstated the statutory text as "all or substantially all" (as opposed to "all or a substantial portion") during the oral argument. See Transcript of Oral Argument at 36:7-10, Life Techs. Corp. v. Promega Corp., 137 S. Ct. 734 (2017) (No. 14-1538).

161. Deepsouth Packing Co. v. Laitram Corp., 406 U.S. 518, 524 (1972).

162. See Brief for the United States as Amicus Curiae Supporting Petitioners at 23-26, Life Techs. Corp. v. Promega Corp., 137 S. Ct. 734 (2017) (No. 14-1538), 2016 WL 4728374 at $* 23-26$ (discussing that if the statute required the supply of all the components, a "domestic 
proportionality test quickly becomes difficult to enforce. For this reason, the Supreme Court was correct not to rule on the matter in Life Technologies. While practitioners may have appreciated more guidance on how to interpret \271(f), the Court's opinion served a practical purpose.

\section{B. The Supreme CourT's Pragmatic ApProACH}

Although the Supreme Court's minimalist decision in Life Technologies seemingly gave little practical advice on how to interpret the statute, the simple "one is not enough" decision was sufficient for the Court's purposes.

The unusual ability of the Federal Circuit to use its expertise to construe patent law for the entire nation, without the benefit of competing analysis from its twelve sister Circuits, gives the Supreme Court a special role in reviewing its decisions. ${ }^{163}$ The Court must redirect the Federal Circuit where it misinterprets patent law, as there are no other circuit courts to redirect a wayward Federal Circuit. At the same time, the Supreme Court should exhibit restraint and allow the Federal Circuit and district courts to fully explore the various factual contours of a question before intervening to provide its own standards or rules.

The Court's opinion achieved these two ends: First, pointing to its recent Microsoft decision in its analysis, the Court's opinion thwarted the Federal Circuit's expansive definition of "substantial portion."164 Second, the Court's opinion opened up the statute for further argument in the lower courts. The questions identified above ${ }^{165}$ - how to correctly quantify "substantial portion," whether by proportion or otherwise, as well as how to appropriately define "component" and interpret inducement under the statute-are challenging and may be more fully illuminated by future cases. Seeing how the statute behaves with different fact patterns allows the courts to consider how it should be applied to various numbers of components and levels of intent to evade patent infringement liability. By leaving these questions open for further litigation in lower courts, the Supreme Court avoided needless speculation about how actors might try to circumvent the law.

supplier could have avoided liability by supplying all but one of the components to the foreign assembler").

163. See Rochelle Cooper Dreyfuss, What the Federal Circuit Can Learn from the Supreme Courtand Vice Versa, 59 AM. U. L. REV. 787, 794-95 (2010) (discussing the relationship between the Federal Circuit and the Supreme court).

164. See Life Techs. Corp. v. Promega Corp., 137 S. Ct. 734, 742 (2017).

165. See supra Section IV.A. 


\section{Unwinding the Federal Circuit's Expansive Interpretation}

The Federal Circuit's decision in Life Technologies was expansive. ${ }^{166} \mathrm{By}$ considering any necessary component to be a "substantial portion," the decision allowed for the supply of nearly any component to attach liability under $\int 271(\mathrm{f})(1)$. If the component was required to make the patented invention function, it could be considered a "substantial portion." Few, if any, components of a patent are unnecessary for the functioning of that invention. Thus, the Federal Circuit effectively expanded $\$ 271(f)(1)$ liability to attach to the supply of any component. ${ }^{167}$ The Federal Circuit's opinion further expanded the application of $\int 271(\mathrm{f})(1)$ by allowing a party to "induce itself" and thus imposed unprecedented liability under the statute.

The Federal Circuit did not observe the presumption against extraterritoriality when it broadened $\int 271(\mathrm{f})(1)$. Section $271(\mathrm{f})$ is a clear exception to the presumption against extraterritoriality, but the presumption should still limit the extent to which the statute is applied. "Even ... when a statute provides for some extraterritorial application, the presumption against extraterritoriality operates to limit that provision ...." 168 The Supreme Court was clear in its recent Microsoft decision that the Federal Circuit had expanded the scope of patent law too broadly and that the presumption against extraterritoriality meant that it should limit the reach of patent laws overseas. ${ }^{169}$ However, the Federal Circuit did not heed this cautionary precedent. Instead, the Federal Circuit's expansive interpretation amplified extraterritorial implications of the statute and had the potential to "undermine the international system of national patents and lead to a type of U.S. patent imperialism." 170

As the Supreme Court had recently stated that "the presumption [against extraterritoriality] tugs strongly against construing \271(f)" broadly, it is unsurprising that the Court reversed the Federal Circuit's opinion in Life Technologies. ${ }^{171}$ The Federal Circuit is the only Article III appellate court that has

166. The Federal Circuit has a history of expansive interpretations of $\int 271(\mathrm{f})$. See Fernandes, supra note 151, at 89-93 (discussing Eolas Technologies, Inc. v. Microsoft Corp, 399 F.3d 1325 (Fed. Cir. 2005) (holding that $\int 271(\mathrm{f})$ is applicable to all varieties of patents and components); Union Carbide Chems. \& Plastics Tech. Corp. v. Shell Oil Co., 425 F.3d 1366 (Fed. Cir. 2005) (holding that $\int 271$ (f) is applicable to method claims); AT\&T Corp. v. Microsoft Corp., 414 F.3d 1366 (Fed. Cir. 2005) (holding that software was a "component" under the statute because the statute is not limited to tangible components and that supplying a master disk with that software was considered a "supply")).

167. See Life Techs., 137 S. Ct. at 741.

168. Morrison v. Nat'l Austl. Bank Ltd., 561 U.S. 247, 265 (2010).

169. See Microsoft Corp. v. AT\&T Corp., 550 U.S. 437, 442 (2007).

170. Bernard Chao, Patent Imperialism, 109 Nw. U. L. REv. OnLINE 77, 86 (2014).

171. Microsoft, 550 U.S. at 455; see Life Techs., 137 S. Ct. at 742. 
national, rather than regional, jurisdiction, hearing cases based on subject matter, including all patent appeals. ${ }^{172}$ Splits creating different precedent within the Circuits and indicating the need for Supreme Court review are unavailable. ${ }^{173}$ The Federal Circuit thus makes the law for the entire nation, unless the Supreme Court steps in to overrule or amend a decision. ${ }^{174}$ This means that the Supreme Court must monitor the Federal Circuit's decisions much more closely, and must take action when it disagrees with an opinion, as there is no other judicial body to oppose the Federal Circuit.

As a result, the Supreme Court has increased both the number of Federal Circuit cases it reviews and the scrutiny of its review. ${ }^{175}$ While the Court's reversal rate of Federal Circuit decisions is not substantially greater than that of the other circuits, ${ }^{176}$ the Supreme Court seems to have a particular interest in patent cases decided by the Federal Circuit. ${ }^{177}$

The Federal Circuit was created to be a specialized court in an attempt to reduce the dockets of the regional circuits and enable technically proficient judges to oversee patent cases. ${ }^{178}$ When Congress created the Federal Circuit, critics warned that judges might get "tunnel vision" and view patent cases in a vacuum, without considering of other areas of the law. ${ }^{179}$

It is possible that the Supreme Court, a generalist court, has reviewed so many Federal Circuit opinions in an attempt to reconcile its specialist patent jurisprudence with more comprehensive considerations. ${ }^{180}$ For example, the Federal Circuit's opinion in Life Technologies included a thorough review of the

172. See Daniel Kazhdan, Beyond Patents: The Supreme Court's Evolving Relationship with the Federal Circuit, 94 J. PAT. OFF. SOC'Y 275, 276 (2012) (describing the Federal Circuit as "the only non-regional court of appeals").

173. See Timothy R. Holbrook, Is the Supreme Court Concerned with Patent Law, the Federal Circuit, or Both: A Response to Judge Timothy B. Dyk, 16 CHI.-KEnT J. InTELL. Prop. 313, 315 (2016) ("No ... splits exist in patent law given the Federal Circuit's national jurisdiction.”).

174. See Dreyfuss, supra note 163, at 805 (describing the Federal Circuit as a "court of last resort" when the Supreme Court does not act).

175. See Kazhdan, supra note 172, at 279-82 (discussing the rising rate and harsher tone of Supreme Court review of Federal Circuit patent cases).

176. See Timothy B. Dyk, Thoughts on the Relationship Between the Supreme Court and the Federal Circuit, 16 CHI.-KEnT J. InTELl. Prop. 67, 71-72 (2016) (noting that the reversal rate at the Supreme Court from 2006 to 2015 for all circuits, except the First Circuit, were at or above $60 \%)$.

177. See Holbrook, supra note 173, at 313-15, 319 (describing the Supreme Court's relationship to patent cases and stating that " $[\mathrm{t}]$ he Supreme Court is interested in patent law far more than the other areas").

178. See Dreyfuss, supra note 163, at 788-90 (describing the creation of the Federal Circuit as a specialized court).

179. Id. at 790 .

180. See Holbrook, supra note 173, at 316 (discussing the Supreme Court acting as an antidote to the "judicial myopia" of the Federal Circuit's patent law decisions). 
technology at issue, precedent, and statutory interpretation, but it vigorously protected the patent without regard to the national and worldwide implications of doing so. ${ }^{181}$ The Supreme Court's reversal interpreted $\int 271(\mathrm{f})$ much more narrowly, limiting the protection of patents extraterritorially. "The Court's interest here [was] not simply patent law: it [was] a broader interest in reformulating and bolstering the presumption against the extraterritorial application of U.S. law." 182 Unlike the Federal Circuit, "the Supreme Court does not view patent law as distinct from other areas of the law." "183

The Supreme Court must take an active role in reviewing Federal Circuit opinions both because of the Court's desire to interpret patent law in concert with other areas of the law and because of the Federal Circuit's role as a national appellate court. And the Court has done so in recent years. ${ }^{184}$ The Supreme Court's reversal of the Federal Circuit in Life Technologies fit into this pattern and was an important action to prevent the Federal Circuit's sweeping interpretation of $\int 271(\mathrm{f})(1)$ that easily expanded patent protection across U.S. borders for the supply of any component from the United States. Legal practitioners, inventors, and others involved in patents may be unsatisfied that this decision does not give them more guidance on how to fully understand \271(f), but by reversing the Federal Circuit, the Supreme Court has enabled that to happen in the future. The statute is now able to further percolate in the lower courts where its interpretation can be worked out, which will give the Court a better idea of how to address it in the future. Congress, of course, may choose to directly amend the statute and offer clarification, expediting the process.

\section{Percolation in Lower Courts}

Percolation is the "mechanism[] through which case law can be critiqued, reexamined, tested, and corrected, and issues worthy of Supreme Court review can be flagged." 185 As a result, courts can identify more issues related to the statute, as well as correct unintended consequences. Percolation of the statute in lower courts ripens it for the Supreme Court to clarify in the future. The Supreme Court "can derive important information from the fact that several courts [below] have confronted the same problem or resolved the same legal issue in similar ways." "186 Further, percolation can help the Supreme Court

181. See supra Section III.B.

182. Holbrook, supra note 173 , at 316.

183. Id.

184. See Dreyfuss, supra note 163, at 792-93 (discussing recent cases that show the Supreme Court's recent increase in intervention in patent law).

185. Paul R. Gugliuzza, Saving the Federal Circuit, 13 CHI.-Kent J. InTELL. Prop. 350, 351 (2013).

186. Rochelle C. Dreyfuss, Percolation, Uniformity, and Coherent Adjudication: The Federal 
shape its own approach, as the Court will be aware of cases in lower courts that are addressing similar issues. "And because the reviewed court will often have considered prior courts" resolutions, its decisions will usually provide the Justices with an understanding of the reason it deviated." 187 These factors allow the Supreme Court to have a more thorough understanding of the landscape surrounding the issue at hand, enabling it to better clarify the doctrine.

Percolation of $\int 271(\mathrm{f})$ in lower courts after Life Technologies will likely have an important role in determining relevant issues, as well as the unintended consequences of proposed solutions. For example, a lower court could institute a proportionality test similar to the one suggested above. ${ }^{188}$ If a court found the proportion to be too large or too small, the court could try a different number. A court could attempt another approach altogether if the court found the proportional test too easily evaded. Further, different courts may employ different definitions of "component" in interpreting the statute, with varying results. The courts will also be able to analyze the extent to which knowledge and intent play a role in $\int 271(\mathrm{f})$ infringement liability. Percolation allows for experimentation, and the trial and error inherent in experimentation uncovers strategies that work and those that fail. It is important that this trial and error take place in the lower courts before the Supreme Court can make a defining decision. For this reason, the Court's Life Technologies opinion was appropriately circumspect in allowing the statute to percolate further in the lower courts.

\section{CONCLUSION}

The Supreme Court's opinion in Life Technologies was pragmatic. Practitioners may disagree, as "one is not enough" does not address how many more components create a "substantial portion," nor does it indicate how notions of knowledge and intent factor into the analysis. However, the decision did achieve two important goals. First, it reversed the expansive Federal Circuit decision that disregarded the longstanding presumption against extraterritoriality and could have had harmful consequences on an international scale. Second, the Supreme Court's decision enabled \$271(f) to percolate further in the lower courts. The Court's opinion only said what it needed to say to reverse the Federal Circuit and left the remainder of the statute open for interpretation. The Supreme Court may be presented with another opportunity in the future to further clarify $\$ 271(\mathrm{f})$, taking into consideration new outcomes and ideas explored by lower courts.

Circuit Experience, 66 S.M.U. L. REV. 505, 525 (2013).

187. Id. at 526 .

188. See supra Section IV.A. 
Without clear direction from Congress, the decision in Life Technologies, with its virtues and faults, was all the Supreme Court could practically achieve on the limited record before it. Prior to the enactment of $\int 271(\mathrm{f})$, the Supreme Court invited Congress to create policy rebutting the presumption against extraterritoriality if it desired. Congress eventually wrote $\int 271(\mathrm{f})$ to do just that -it created an exception allowing limited patent protection beyond the U.S. borders, but poorly defined the extent of that limit. The language of \271(f) is ambiguous and does not give clear indication as to how Congress intended the statute to apply. While the Court has positioned itself to hear future argument on $\int 271(\mathrm{f})$, Congress may resolve to clarify, amend, or completely re-write the statute before the Court reconsiders.

Meanwhile, inventors may choose to seek foreign patents to protect their inventions abroad rather than attempt to defend them through murky U.S. patent statutes like $\int 271(\mathrm{f})$. The Supreme Court has suggested this alternative in numerous opinions as a sensible means of proceeding without depending on the U.S. legal system or violating longstanding traditions of patent territoriality. ${ }^{189}$

189. See Deepsouth Packing Co. v. Laitram Corp., 406 U.S 518, 531 (1972) (“Respondent holds foreign patents; it does not adequately explain why it does not avail itself of them."); see also Microsoft Corp. v. AT\&T Corp., 550 U.S. 437, 456 (2007) ("If AT\&T desires to prevent copying in foreign countries, its remedy today lies in obtaining and enforcing foreign patents."). 
